\title{
Transatlantica
}

Revue d'études américaines. American Studies Journal

2 | 2014

Aesthetics of Theory in the Modern Era and Beyond / Photographie documentaire

\section{Shannon Cain, ed., Roadside Curiosities. Stories about American Pop Culture}

Leipzig, Leipziger Universitätsverlag, 2014

\section{Nicolas Labarre}

\section{CpenEdition \\ Journals}

\section{Electronic version}

URL: https://journals.openedition.org/transatlantica/7249

DOI: $10.4000 /$ transatlantica.7249

ISSN: $1765-2766$

Publisher

Association française d'Etudes Américaines (AFEA)

\section{Electronic reference}

Nicolas Labarre, "Shannon Cain, ed., Roadside Curiosities. Stories about American Pop Culture",

Transatlantica [Online], 2 | 2014, Online since 20 December 2019, connection on 02 February 2023

URL: http://journals.openedition.org/transatlantica/7249; DOI: https://doi.org/10.4000/transatlantica. 7249

This text was automatically generated on 2 February 2023

\section{(c) (†) $\odot$}

Creative Commons - Attribution-NonCommercial-NoDerivatives 4.0 International - CC BY-NC-ND 4.0 https://creativecommons.org/licenses/by-nc-nd/4.0/ 


\title{
Shannon Cain, ed., Roadside Curiosities. Stories about American Pop Culture
}

Leipzig, Leipziger Universitätsverlag, 2014

\author{
Nicolas Labarre
}

\section{REFERENCES}

CAIN, Shannon, ed., Roadside Curiosities. Stories about American Pop Culture, Leipzig, Leipziger Universitätsverlag, 2014, 253 pages, ISBN 978-3-86583-633-5, 14,90 euros.

1 Roadside Curiosities is a collection of contemporary short stories which promises to marry "highbrow" and "lowbrow," "literary fiction to American popular culture" (back cover). This union takes the form of twenty short stories selected by Shannon Cain, herself a short-story writer as well as a creative writing teacher, featuring Madonna, a superhero, the spectral image of Cary Grant, the hero of the Donkey Kong video game and more.

2 In her introduction to the collection, Cain surprisingly resurrects a disapproving view of pop culture as something "simple, easy, and shallow" (7), "joyous and uncontrolled" yet "slick, corporate, mainstream and profit-driven" (8), a culture that is "ultimately not that which sustains us spiritually" (9). Her initial position, in other words, is very close to that of the mid-20th century American intellectuals, fascinated with a popular culture they knew all too well but felt they had a duty to condemn. An archetypal example of this view would be Dwight MacDonald, excoriating middlebrow and lowbrow culture in "A Theory of Mass Culture" (1953), while buying comics for his children and maintaining an abiding love of Hollywood cinema. Consequently, Cain's interest lies not in the popular cultural objects themselves but in their function for their users, and in what happens when "literature as high art examines pop culture as low art" (7). Unlike MacDonald, she does identify a positive function for popular 
culture: the creation of communities, through shared experience. "We consume pop culture, maybe, because by hanging together in enjoyment of our humanity, we begin to see that we're all sharing the same road" (10). Accordingly, the stories she selected devote more attention to "love, loss, hatred, compassion, beauty" (9) than to the "roadside curiosities", Americana or pop cultural objects promised by the title, though of course, the marriage of pop culture and literature is one which has long been consumed, if only in the writings of Tom Wolfe or James Ballard for instance.

3 For all the ambivalence of Cain's theoretical position, some of the stories do focus on pop culture as such. Lydia Millet's "Sexing the Pheasant," the opening story in the collection is indeed "as pop culturesque as you can get" (Bloom and Cain, 2013, n.p.), featuring Madonna, Guy Ritchie and an unpleasantly dead pheasant. Similarly "Jumpman vs. the Ape," by Matt Bell, examines the travails of jumpman, the protoMario in the original Donkey Kong video game from 1981. Even there, however, the connection to American pop culture is slight, since Donkey Kong is a Japanese video game, by one of the most eminent creators in the field, Shigeru Miyamoto. Further into the volume, one of the stories does mention what could be a superhero, in the form of a folk tale, possibly an illusion ("Things my Father Said," by Gary Jackson) and another offers a very postmodern take on the possible sighting of Cary Grant in his role in North by Northwest by a modern American family ("The Digitally Enhanced Image of Cary Grant Appears in a Cornfield in Indiana," Michael Martone). These exceptions notwithstanding, most of the later stories in the collection are connected only tangentially, if at all, to the culture industry. Instead, their common focus is on smallscale lives and events, on the happiness to be found in the cracks, details and unwanted places of the United States. The moving final story of the collection, "Oranges," by Anthony Doerr, condenses the passing of a generation over five pages, turning the peeling of an orange, the smell and the color of the fruit, into resonant occurrences upon which memories and emotions can hang.

4 The stories vary greatly in tone, from lightly humorous to horrific, but they all share an interest in the ephemeral, in transient feelings, artifacts and cultural objects: a novelist relishes her discovery and use of the word "pussy" in Meg Pokrass's "The Serious writer and her pussy;" a woman turns a questionnaire about air quality into the story of her desperate life ("Domestic Air Quality," Kelcey Parker); etc. They also share a distinctly nostalgic tone, in their avoidance of almost anything digital. With a few exceptions, the stories in Roadside Curiosities could be placed at any point between 1970 and 2000, even though they were all written between 2004 and 2013. The communities described in these pages are all united by physical places, physical artefacts. One of the two stories in which social media features, "Rumm Road," by Alice Eliott Dark, turns them into overpowering anxiety machines, leading parents to seek refuge in James Joyce, while mourning the "loss of [their own] innocence" (54). Likewise, in Shannon Cain's own "The Nigerian Princes," an attempt to turn the table on internet scammers fails spectacularly but ends with the creation of an accidental multi-generational family. As indicated by Cain in her introduction, "these stories [...] speak in animated chatter with one another" (9), and the story they tell is mostly that of adjusting to life in the late 20th century, amidst confusing and ambiguous signals, such as these sirens the parents in "Rumm Road" listen to in anguish.

5 Roadside Curiosities does not fulfill the program promised by its subtitle and by its backcover. It deals with the popular, rather than with popular culture as we generally mean 
it; that task may best be left to science-fiction writers (William Gibson, Laurent Queyssi, etc.), considering the pace of the transformations and reinventions within the culture industry. It nevertheless functions as a volume, presenting a composite view of life on the many margins of the United States, one which could, perhaps, have been more appropriately entitled "Roadside Communities."

\section{BIBLIOGRAPHY}

Bloom and Shannon CAIN, "Embracing the Mess, With Shannon Cain," Bloom, 2013, http://bloomsite.com/2013/08/22/best-of-bloom-embracing-the-mess-with-shannon-cain/ (last accessed on January 26, 2015).

INDEX

Subjects: Recensions

\section{AUTHORS}

NICOLAS LABARRE

Université Bordeaux Montaigne 